\title{
Profesyonel Turist Rehberlerine Yönelik Cinsel Taciz İle İlgili Bir Araştırma
} A Study on Sexual Harassment to Professional Tour Guides

\author{
Dr. Öğr. Üyesi Gülsüm YILDIRIM \\ Recep Tayyip Erdoğan Üniversitesi, Ardeşen Turizm Fakültesi, Türkiye \\ Recep Tayyip Erdoğan University, Ardeșen Tourism Faculty, Turkey \\ E-Mail: gulsun.yildirim@erdogan.edu.tr \\ Dr. Öğr. Üyesi Özlem ÖZBEK \\ Bandırma Onyedi Eylül Üniversitesi, Gönen Meslek Yüksekokulu, Türkiye \\ Bandirma Onyedi Eylül University, Gönen Vocational High School, Turkey \\ E-Mail: ozlemtekin10@gmail.com
}

$\ddot{O} z$

Amaç ve Önem: Bu çalışmada, Türkiye'de, turist rehberlerinin mesleğinde sosyolojik bir problem olarak ifade edilebilen, cinsiyet temelli sorunlardan cinsel taciz deneyimlerinin ortaya çıarılması amaçlanmıştır. Tur yönetimini, meslek aidiyetini ve turist rehberlerinin hizmet kalitesini etkileyebilen bir problem olması sebebiyle önem arz etmektedir.

Yöntem: Cinsel taciz gibi bir tutumun Türkiye'yi ziyaret eden misafirlerde söz konusu olup olmadığını ve bunun rehberlerin mesleğine etkisini ortaya çıkarmak amacıyla Türkiye'deki tüm profesyonel turist rehberlerine anket uygulanmış ve açık uçlu soru yöneltilmiştir. Çalışmada karma yöntemlerden gömülü desen araştırma kullanılmıştır.

Bulgular: Bu kapsamda araştırma sonucunda, misafirlerde erkek turist rehberlerine yönelik cinsel taciz eğiliminin daha yüksek olduğu ortaya çıkmıştır. Açık uçlu soruda ise katılımcılar, cinsiyet temelli sorunlar konusunda misafirlerden ziyade, tur personelinin davranışlarında problemler olduğunu ve tur yönetimini olumsuz yönde etkilediğini ifade etmişlerdir.

Özgünlük/ Bilimsel Katkıs İlgili alan yazında, bu konuda turizm işletme personelleri ile ilgili çalışmaların yapıldığı fakat turist rehberleri ile ilgili bir araştırmanın olmadığ 1 tespit edilmiştir. Bu çalışmada özellikle Profesyonel turist rehberlerinin mesleki sorunlarından cinsel taciz konusuna değinilmiştir.

Anahtar Kelimeler: Turist rehberleri, cinsel taciz, profesyonel turist rehberliği.

Makale Türü: Araştırma makalesi

\begin{abstract}
Purpose and Importance: In this study, it is aimed to reveal sexual harassment experiences of tourist guides in Turkey. Sexual harassment is one of gender based problems which can be expressed as a sociological problem in the profession of tourist guides. The study topic is important because results will reveal the impact of attitude of sexual harassment, which may affect the service quality of tour guides and their professional belonging.
\end{abstract}

Methodology: A questionnaire with an open-ended questions in the end was applied to all tourist guides in Turkey. Grounded theory, which is one of the mixed methods, was used in the study. 


\section{IIIII)}

Turist Rehberliği Dergisi (TURED) \& Yıl. 2019, Cilt. 2, Sayı. 2

Journal of Tour Guiding (JOTOG) \& Year. 2019, Volume. 2, Issue. 2

Findings: As a result of this research, it was found that the sexual harassment tendency towards male tourist guides was higher among the guests. In the open-ended question, the participants stated that there were problems in the behavior of tour staff rather than guests in terms of gender-based problems and that they negatively affected tour management.

Originality/Value: In the related literature, it has been determined that there are studies about tourism management personnel but there is no research about tourist guides. The issue of sexual harassment, which is one of the professional problems of professional tourist guides, will be discussed.

Keywords: Tourist guides, sexual harassment, professional tourist guidance.

Paper Type: Research article

Giriş

Erkek ya da kadın fark etmeksizin iş hayatında cinsel taciz ile karşı karşıya kalma söz konusu olabilmektedir. Yapılan çalışmalar dünyanın farklı ülkelerinde, farklı sektörlerde çalışanların cinsel tacize maruz kaldığını ortaya koymuştur (Wasti, Bergman, Glomb ve Drasgow, 2000). Cinsel tacize maruz kalanlarda iş tatminsizliği ve bazı sağlık sorunları ortaya çıkmakta ve bazen bu durum işten ayrılmayla da sonuçlanabilmektedir (O’Donohue, Downs ve Yeater, 1998).

İlgili alan yazın incelendiğinde, en fazla cinsel taciz olayının yaşandığı sektörlerin içerisinde, oranı en yüksek olanlardan birinin turizm sektörü olduğu görülmektedir (Hoel ve Einarsen, 2003; Eller, 1990). Çalışanlar ve müşteriler arasında yakın temas gerektirmesi ve müşteri memnuniyetine verilen önemin yüksek olmas1, turizm sektöründe cinsel taciz olaylarının yaşanmasının en önemli etkenleri olarak görülmektedir (Poulston, 2008; Gilbert vd., 1998). Özellikle ataerkil kültüre sahip toplumlarda ve işsizliğin yüksek olduğu ülkelerde cinsel tacizle daha fazla karşılaşıldı̆̆ı ileri sürülmüştür (Merkin, 2009; Luthar \& Luthar, 2007). Buradan hareketle, benzer özelliklere sahip bir ülke olan Türkiye'de, turist rehberlerinin karşılaşabileceği meslek sorunlarından biri olan cinsel taciz sorununun söz konusu olup olmadığının ortaya çıkarılması hedeflenmiştir. Daha önceki araştırmalarda, turizm sektörünün farklı çalışanları ile ilgili bulgular ortaya çıkmasına (Unur v\& Şanlı, 2018) karşın, turist rehberlerinin bu olguya karşı deneyimlerini ortaya çıkarmaya yönelik çalışma yapılmadığı dikkati çekmiştir. Bu bakımdan çalışmanın önemli olduğu düşünülmektedir.

\section{Cinsel Taciz}

Cinsel tacize bakış açısı kültürden kültüre değiştiğinden, cinsel taciz ile ilgili farklı tanımlar yapılmıştır. Dolayısı ile farklı ülkelerde cinsel taciz ile ilgili farklı tanımlar yapılmaktadır. Buna karşın cinsel taciz kapsamındaki davranışlar tüm dünyada benzer nitelikler taşımaktadır. Cinsel taciz kavramını ilk olarak Catherine Mac Kinnon'un 'Sexual Harassment of Working Woman' isimli kitabında tanımlanmıştır (Mimaroğlu ve Özgen, 2008).

Cinsel taciz, fiziksel ve sözel nitelik taşıyan, istenmeyen herhangi bir cinsel davranış (Oktay, 2001: 75) olup, çok çeşitli cinsel taciz örnekleri bulunmaktadır. Cinsel taciz; davranışın türüne, tacizin seviyesine, tacizcinin kim olduğuna ve taciz koşullarına göre farklı sınıflara ayrılmaktadır (Lin, 2006). Cinsel tacize, tekrar edilen ve istenmeyen sözel ve fiziksel olarak yapılan cinsel yaklaşımlar, cinsellik içeren ifadeler, göz süzme, istenmeyen fiziksel dokunuşlar örnek olarak verilebilir. Ayrıca, cinsel ayrım güden sözler, cinsiyetin bir çıkar sağlama aracı olarak kullanılması, karşı tarafın istemediğini belirtmesine rağmen sürekli olarak yinelenen flört teklifleri (Arslan ve Vasilyeva, 2003, Solmuş, 2005; Oktay, 2001) şeklinde siralanabilecek birçok cinsel taciz örneği bulunmaktadır. Huang (1995)'e göre cinsel tacizi yapan kişiler; 


\section{IIIII)}

Turist Rehberliği Dergisi (TURED) \& Yıl. 2019, Cilt. 2, Sayı. 2

Journal of Tour Guiding (JOTOG) \& Year. 2019, Volume. 2, Issue. 2

yabancılar (sıradan insanlar) ve yabancı olmayanlar (iş arkadaşları, müşteriler gibi..) şeklinde gruplandırılmaktadır.

Alan yazında cinsel taciz ile ilgili birçok çalışma yapılmışıı. Bu çalışmalardan bazıları cinsel taciz ve güç mesafesini ilişkilendirmiştir (Yücel ve Koparan, 2010; Mimaroğlu ve Özgen, 2008). Yücel ve Koparan (2010) yaptıkları çalışmada Sanayi Bölgesindeki işletmelerde çalışanların güç mesafesini algılama değeri boyutundaki düzey ve eğilimleri ile bu eğilimlerin örgütlerdeki cinsel taciz davranışlarına etkisini incelemiştir. Araştırmalarının sonucunda güç mesafesi ile cinsel taciz arasında pozitif yönlü bir ilişki olduğu ortaya çıkmıştır.

Sözer ve Cleveger (2010) üniversite kampüslerinde uygulanan tecavüz ve cinsel tacizi önleme eğitim programlarının etkililiğini incelemiştir. $\mathrm{Bu}$ araştırmacılar, dünyada üniversitelerde cinsel taciz ve tecavüzün yaygın olduğunu ileri sürmüşler ve bunun altında yatan nedeni ise üniversitelerde genç ve yalnız başına yaşayan bayan nüfus oranının yüksek olmasına bağlamışlardır. Her ne kadar dünyada farklı ülkelerde cinsel taciz ve tecavüzü önleme konusunda eğitimler uygulansa da (Ullman, 2007), Türkiye'deki üniversitelerde cinsel taciz ve tecavüzü önleme konusunda sistematik bir program veya eğitim bulunmamaktadır.

Güç mesafesinin ve işsizliğin yüksek olduğu, ataerkil kültüre sahip ülkelerde cinsel tacizle karşılaşma olasılık oranı daha yüksektir (Merkin, 2009; Luthar ve Luthar, 2007; Wasti vd., 2000; Luthar ve Pastille, 2000). Buna ek olarak; modern çalışma hayatında kadınların erkekler tarafindan cinsel tacize maruz kalma oranı daha fazladır (Posner, 1999).

O’Donohue, Downs ve Yeater (1998)'e göre cinsel tacizin bireylere, örgütlere ve topluma yönelik olumsuz etkileri olmaktadır. İş yerinde cinsel tacizle karşılaşanlar, yaptıkları işten nefret etme eğiliminde olup, işe gitmenin alçaltıcı ve küçük düşürücü olduğunu ifade etmektedirler. Yöneticilere yapılan şikâyetlere rağmen, herhangi bir müdahale edilmemekte ve şikâyetleri belirtenlerden en az bir tanesi işi bırakmaktadır (Becton, Gilstrap ve Forsyth, 2017). Cinsiyet ayrımı ve cinsel taciz ile iş tatmini arasında ilişki bulunmaktadır (Antecol, Barcus ve Cobb-Clark, 2009). Cinsel tacize maruz kalanlar bazı sağlık sorunları yaşamaktadır. Bunlardan bazıları; baş ağrısı, kilo kaybı, yorgunluk, depresyon, endişe korku, suçluluk, çaresizlik, sinirlilik şeklindedir (Lin, 2006: 53).

Cinsel taciz ile iş tatminsizliği ve işten ayrılma niyeti arasındaki bağ farklı ülkelerde farklı şekillerde ortaya çıkmaktadır. Bu konu ile ilgili Amerika ve Türkiye arasında karşılaştırma yapılmış ve Türk kadınlarının Amerikalı kadınlara göre cinsel tacize uğrasalar bile daha az işten ayrıldıkları ortaya çıkmıştır (Wasti vd., 2000). O'Donohue, Downs ve Yeater (1998)'e göre cinsel taciz çalışanların motivasyonunu ve verimliliğini düşürmekte ve iş bırakmayla sonuçlanabilmektedir.

\section{Turizmde Cinsel Taciz}

Çoğu ülkede işyeri problemlerinden biri cinsel tacizdir (Timmerman ve Bajema, 1999). Çok farklı iş alanlarında çalışanlar cinsel taciz ile karşı karşıya kalmaktadır. Bu iş alanlarından biri sağl1k sektörüdür. Spector, Zhou ve Che (2014) yaptıkları çalışmada, 151,347 hemşire içerisinde $25 \%$ inin cinsel tacize maruz kaldığını ortaya koymuştur. Hemşirelerin yanı sıra kadın doktorlar da hastaları tarafından cinsel tacize maruz kalmaktadır (Schneider ve Phillips, 1997).

Askeriyede de cinsel taciz ile karşılaşılmaktadır (Faley vd., 2006). Cinsel taciz davranışına tarım ve madencilik gibi sektörlerde de sıklıkla karşılaşılmaktadır (Saunders ve Am, 2013).

Turizm sektöründe çalışanlar da cinsel tacize maruz kalmaktadır. Eller (1990)'a göre diğer sektörlere kıyasla turizmde cinsel tacize maruz kalma oranı daha yüksektir ve kadınlar 


\section{IIIII)}

Turist Rehberliği Dergisi (TURED) \& Yıl. 2019, Cilt. 2, Sayı. 2

Journal of Tour Guiding (JOTOG) \& Year. 2019, Volume. 2, Issue. 2

erkeklere göre daha fazla bu durumla karşılaşmaktadırlar. Bazı çalıșmalar da bu sonucu desteklemiştir (Hoel ve Einarsen, 2003; European Comission, 1998). Turizm sektörünün yakın ilişki gerektirmesinden ve bu sektörde müşteri memnuniyetinin çok önemli olmasından dolay1 yüksek cinsel taciz riski taşımaktadır (Poulston, 2008; Gilbert vd., 1998). Ayrıca, turizm sektörünün hizmet ağırlıklı bir sektör oluşu, çalışma saatleri ile çalışma koşullarının olağan dış1lığ1, görünüş ve ilginin iyi olması gerekliliği bu riski arttırmaktadır (Mkono, 2010; Eller, 1990; Woods ve Kavanagh, 1994).

Tayvan'da konaklama işletmelerinde staj yapan öğrenciler üzerinde yapılan çalışmada katılımcıların büyük bir çoğunluğunun stajları süresince cinsel tacize maruz kaldığı ortaya çıkarılmıştır (Lin, 2006). Amerika'da, İngiltere'de mezun öğrenciler ve staj yapanlar ile yapılan çalışmalar da benzer sonuçları çıkarmıştır (Worsfold ve McCann, 2000; Woods ve Kavanaugh, 1994). Zimbabwe'de konaklama işletmelerinde staj yapan öğrenciler ile yaptığ 1 çalışmada Mkono (2010), konaklama işletmelerinde cinsel tacizin olağandışı olmadığı ve iş arkadaşlarının, yöneticilerin ve müşterilerin cinsel taciz eğilimi olduğu sonucuna varmıştır.

İster staj yapan öğrenciler olsun ister turizmde normal çalışanlar olsun bu sektörde çalışanların düşük statüye sahip olmaları müşteriler ve yöneticiler tarafından çalışanların taciz konusunda hedef olmalarına neden olmaktadır (Poulston, 2008). Cinsel taciz ve güç arasında bir ilişki olmasından (Yücel ve Koparan, 2010; Mimaroğlu ve Özgen, 2008) yola çıkarak, yaş, ırk, cinsiyet ve sosyal sınıfı içeren güç boyutları (West ve Fenstermaker, 1995) doğrultusunda genç kadınlar risk altındadır.

Turizmde ön büro, yiyecek içecek departmanları gibi ziyaretçilerle yoğun temasın olduğu departmanlarda cinsel taciz daha yaygın görülmekte ve misafirler, arkadaşlar, deneyimli personel bu davranışı yapmaktadır. Ancak çalışanlar en çok müşteriler tarafından cinsel tacize maruz kalmaktadırlar (Poulston, 2008). Yine bu çalışmada, cinsel tacizin bazı çalıșanlar tarafindan kabul edildiği hatta bazen hoş karşılandığı ileri sürülmüştür. Poulston (2008:239)'a göre 'cinsel tacizi kabul edilir bulmayanlar varken turizmde çalışanlardan bir kısmı bunu kabul edilebilir bulduğu sürece, müşteriler davranmaları gerektiği gibi değil de istedikleri gibi davranmaya devam edecektir'. Turizm sektöründe çalışanların yanı sıra turistler de farklı şekillerde taciz edilmektedirler (Alrawadieh, alrawadieh ve Kozak, 2019).

Otellerin cinsel taciz ile ilgili belirli bir politikalarının olmayışı, cinsel taciz ile ilgili duruşmaların halka açık oluşu ve otel yöneticilerinin cinsel taciz olaylarına kayıtsız kalmaları cinsel taciz ile başa çıkmada en önemli eksikliklerden bazılarıdır (Mkono, 2010).

\section{Yöntem}

Araştırmada, turist rehberlerinin mesleğini etkileyen sosyal problemlerden biri olabileceği varsayılan cinsel taciz vb. durumları belirlemek ve bu sorunun meslek yaşamlarına etkisini belirlemek amaçlanmıştır. Bu hedef doğrultusunda hem nicel hem de nitel yöntem tercih edilmiştir. Araştırma verilerinin toplanmasında anket tekniğinden yararlanılmıştır. Anket formunun sonuna açık uçlu bir soru eklenmiş ve katılımcıların kendi cümleleri ile görüşlerinin alınması amaçlanmıştır. Birbirini destekleyen nicel ve nitel yöntemler bir arada olduğundan araştırma karma yöntemli, gömülü desen araştırmasıdır (Creswell, 2017). Araştırma problemi, Türkiye'de çalışmakta olan turist rehberlerinin, cinsiyetleri, medeni durumları, yaş ve çalışma süreleri ile cinsel taciz tutumuna maruz kalmaları arasında anlamlı bir farklılık olup olmadığıdır.

Araştırma Soruları:

1. Profesyonel Turist Rehberleri tur sürecinde misafirlerden cinsel taciz yaklaşımı görmekte midir? 


\section{IIIII)}

Turist Rehberliği Dergisi (TURED) \& Yıl. 2019, Cilt. 2, Sayı. 2

Journal of Tour Guiding (JOTOG) \& Year. 2019, Volume. 2, Issue. 2

2. Profesyonel Turist Rehberleri tur sürecinde ne tür cinsel taciz yaklaşımları görmektedir?

3. Turist rehberleri karşılaştığı cinsel taciz yaklaşımları gibi problemli durumlar söz konusu olduğunda tur yönetimini nasıl gerçekleştirmektedir?

Araştırmanın evrenini Türkiye'de profesyonel turist rehberi unvanına hak kazanmış ve aktif çalışmakta olan turist rehberleri oluşturmaktadır. Veriler Ocak 2019 - Mayıs 2019 tarihleri arasında toplanmıştır. Kolayda örnekleme yöntemi uygulanan araştırmanın anket formu, Türkiye'deki eylemli turist rehberlerine, bütün meslek odalarına anket formunu mail ile göndermek suretiyle ulaştırılmak istenmiştir. Diğer oda yönetimlerinin bilimsel araştırmalara destek olmak istememesi nedeniyle, yanlızca Anro, İro ve Çaro'ya bağl1 4.213 rehbere ulaşılabilmiş ve araştırmaya katılmaya gönüllü 72 turist rehberinden geri dönüş gerçekleşmiştir. Araştırmada, ilk olarak nicel analiz bulgularına sonrasında da nitel analiz bulgularına yer verilmiştir.

Anket formunda öncelikle demografik verilere ilişkin sorulara yer verilmiştir. Demografik soruların ardından, katılımcıların misafirlerden gördükleri uygunsuz davranışların düzeyini belirlemek için Reilly ve arkadaşları (1986) tarafından geliştirilen, Unur ve Şanlı (2018) tarafından Türkçeye uyarlanan ölçek kullanılmıştır. Ölçek maddelerindeki sıklık derecesi için ' $1=$ Hiç', '2=Ara sıra', ' $3=$ Bazen', '4=Çoğunlukla', '5=Her zaman' kullanılmıştır. Cinsel taciz ile karşılaşıldıysa eğer rahatsızlık düzeyi için ' $1=$ Hiç', '2=Biraz', '3=Orta düzeyde', '4=Epey' ve '5=Çok fazla' olarak belirlenmiştir.

Araştırma anketi öncelikle 15 turist rehberine gönderilmiş ve ölçek sorularının anlaş1lır ifadeler olup olmadığ soruya gelen yanıtlardan anket sorularının anlaşılır olduğu tespit edilmiștir ve bu sonuçlar bulgulara eklenmiştir. Elde edilen verilerden yola çıkarak sırasıyla betimsel analizler yapılmış, anket güvenilirliği hesaplanmış, verilerin dağılımı incelenmiş ve dağılıma bağlı olarak farklılık testleri yapılmıştır. Analizler SPSS programı kullanılarak yapılırken anlamlılık düzeyi .05 olarak alınmıştır. Veriler betimsel olarak analiz edilirken frekans, ortalama ve standart sapma değerlerine bakılmıştır. Anket güvenilirliği Cronbach's alpha $(\alpha)$ değeri hesaplanarak bulunmuştur, ölçeğin tamamı için $\alpha=.95$ bulunmuştur. Alt faktörlere bakıldığında İlgili Tavırlar ve Eylemler için $\alpha=.89$ Bir Şey Karşılığında Bir Şey İsteme ve Fiziksel Saldırı için $\alpha=.92$, Ekonomik/Sosyal Merkezli Kaygı için $\alpha=.90$, Öğrenci/Iletişim Merkezli Kaygı için $\alpha=.83$, Müstehcen Tavırlar ve İletișim İsteği için $\alpha=.84$, Sözlü Taciz ve Aşağılama için $\alpha=.73$ olarak bulunmuştur. Ölçeğe ve alt boyutlarına ait $\alpha$ katsayılarının .79 üzerinde olduğu görülmüş ve dolayısıyla anketlerin güvenilir olduğu kanısına varılmıştır. Verilerin normal dağılıma uygun olup olmadığını ortaya koymak amacıyla, Kolmogorov-Smirnov testi uygulanmıştır. Ölçeğin alt faktörlerinin tamamında $\mathrm{p}<.05$ bulunmuş ve dağglımların normal dağılımdan anlamlı bir farklılık sergilediği görülmüştür. Bu durumda fark testleri için parametrik olmayan testlerin uygulanmasına karar verilmiştir. Cinsiyet ve medeni durum değişkenin etkisini test etmek için Mann Whitney U testi yapılmış; eğitim düzeyi, yaş ve çalışma süresinin etkisini belirlemek için ise Kruskal Wallis $\mathrm{H}$ testi yapılmıştır.

Araştırmada nicel yöntemin yanı sıra sosyal gerçekliği öğrenmede iyi bir yol olan ve sosyal olguların keşfedilmesinde, kişilerin durumlara ve olaylara yükledikleri anlamların ortaya çıkarılmasında ve yeni alanların keşfedilmesinde (Leavy, 2014) kullanılan nitel yöntemden de yararlanılmıştır. Bu araştırmada nitel araştırma yaklaşımlarından biri olan fenomenolojiden faydalanılmıştır. Araştırma deseni olarak fenomenoloji seçilmesinin nedeni katılımcıların cinsel taciz deneyimlerinin ortaya çıkarılmak istenmesidir. 


\section{IIIII)}

Turist Rehberliği Dergisi (TURED) \& Yıl. 2019, Cilt. 2, Sayı. 2

Journal of Tour Guiding (JOTOG) \& Year. 2019, Volume. 2, Issue. 2

Nitel verilerin analizi kısmında öncelikle katılımcıların cinsel taciz ile ilgili belirttikleri görüşler bir Word belgesinde toplanmıştır. Sonrasında elde edilen verilerin tamamı okunmuş ve veriler benzer gruplar altında düzenlenmiştir. $\mathrm{Bu}$ düzenlemeler bağlamında temalar oluşturulmuştur. Temaların oluşturulmasında betimsel kodlamadan faydalanılmıştır. Betimsel kodlama Saldana (2009: 98)' a göre konunun belirlenmesinde kullanılan bir kodlama türüdür.

Araştırmanın nitel yöntem kısmında geçerlilik ve güvenirliğin arttırılması adına öncelikle katılımcıların gizliliği sağlanmıştır. Sonrasında çalışmanın doğruluğunu arttırma adın akran incelemesine başvurulmuştur (Lincoln ve Guba, 1985). Geçerliliği arttırma adına elde edilen bulgular zengin bir betimlemeye tabii tutulmuştur. Çalışmanın nitel analiz kısmında güvenirliğin arttırılması için veri seti birden fazla kodlayıcı tarafından gruplandırılmış ve farklılıklar göz önüne alınarak veriler yeniden düzenlenmiştir.

\section{Bulgular}

Araştırma bulgularına dair demografik veriler, araştırma ölçeği alt boyutlarına ait aritmetik ortalama, standart sapma ve standart hata değerleri, kullanılan ölçeğin güvenilirlik analizleri ve alt boyutların normalliğini denetleyen analizler ile, rehberlerin misafirlerden cinsel taciz tutumu görme durumumun, rehberlerin cinsiyet, medeni durum, yaş ve çalışma süresi bağlamında farklılıklarına dair analizler ve nitel bulgular aşağıda tablo ve açılamalar ile sunulmuştur.

Tablo 1. Kat1lımc1lara Ait Demografik Veriler

\begin{tabular}{|c|c|c|c|c|c|c|c|}
\hline Kategori & Tanım & n & $\%$ & Kategori & Tanım & $\mathbf{n}$ & $\%$ \\
\hline \multirow{2}{*}{ Cinsiyet } & Kadın & 37 & 51.4 & \multirow{4}{*}{ Eğitim Düzeyi } & Lise & 3 & 4.2 \\
\hline & Erkek & 35 & 48.6 & & Ön Lisans & 2 & 2.8 \\
\hline \multirow{4}{*}{ Yaşınız } & $<30$ & 11 & 15.3 & & Lisans & 40 & 55.5 \\
\hline & $31-35$ & 12 & 16.7 & & Lisansüstü & 27 & 37.5 \\
\hline & $36-40$ & 10 & 13.9 & \multirow{4}{*}{ Çalışma Süresi } & $1-5$ y1l & 12 & 16.7 \\
\hline & $40<$ & 39 & 54.2 & & $6-10$ y1l & 12 & 16.7 \\
\hline \multirow{2}{*}{ Medeni Durum } & Evli & 44 & 61.1 & & $11-20 \mathrm{y} 1 \mathrm{l}$ & 21 & 29.2 \\
\hline & Bekâr & 28 & 38.9 & & $20+y 11$ & 27 & 37.5 \\
\hline \multicolumn{2}{|c|}{ Toplam } & 72 & 100,0 & \multicolumn{2}{|c|}{ Toplam } & 72 & 100,0 \\
\hline
\end{tabular}

Katılımcıların 37 kadın ve 35 erkek olmak üzere 72 katılımcı ile sınırlı kalması durumu, turist rehberlerinin cinsel taciz konulu bir araştırma ile ilgili görüş bildirmek istememesi olarak yorumlanabilmektedir ve bu durum araştırma sınırlılığ olarak araştırmaya katılımeı olan 72 kişi içerisindeki cinsiyet dağılımı yarı yarıyadır. Eğitim seviyesinin çoğunlukla lisans ve lisansüstü olması dikkat çekmektedir. Türkiye'de turist rehberliği eğitimi ön lisans, lisans ve yüksek lisans seviyesinde gerçekleştirilen örgün öğretim sistemiyle gerçekleştirilmektedir. Turist rehberliği eğitiminin farklı sistemlerle gerçekleştiği bir ülke olan Türkiye'de, çoğunlukla eğitim seviyesi yüksek rehberlerin görüş bildirmek istemesi olarak yorumlanabilmektedir. Meslek tecrübesi sorusunda ise, $\% 27$ oranla 20 yıldan daha fazla tecrübeli rehberlerin katılımcı olması bulgusu söz konusudur. İkinci olarak, \%21 oranla 11-20 y1llık mesleki deneyimi olan rehberler katılımeı olarak araştırmaya katkı sunmuştur. Katılımcıların \%24'ü ise 1-10 y1llık mesleki deneyime sahiptir. Verilerin betimsel analizi sonucunda, çoğunlukla katılımcıların 1-10 yıllık mesleki deneyime sahip olduğu ve bunu yüksek eğitimli ve mesleki deneyimi 20 yıldan fazla olan, çoğunlukla evli ve 40 yaş üstü katılımcıların takip ettiği görülmektedir. 
Turist Rehberliği Dergisi (TURED) \& Yıl. 2019, Cilt. 2, Sayı. 2

Journal of Tour Guiding (JOTOG) \& Year. 2019, Volume. 2, Issue. 2

Tablo 2. Araştırma Ölçeği Alt Boyutlarına Ait Aritmetik Ortalama, Standart Sapma ve Standart Hata Değerleri

\begin{tabular}{lcccc}
\hline \multicolumn{1}{c}{ Alt Boyutlar } & $N$ & $\overline{\mathrm{X}}$ & $\boldsymbol{S S}$ & $\mathrm{Sh}_{\overline{\mathrm{x}}}$ \\
\hline İlgili Tavırlar ve Eylemler & 72 & 2.31 & 0.85 & 0.10 \\
Bir Şey Karşılığında Bir Şey İsteme ve Fiziksel Saldırı & 72 & 1.16 & 0.55 & 0.07 \\
Müstehcen Tavırlar ve İletişim İsteği & 72 & 1.97 & 0.70 & 0.08 \\
Sözlü Taciz ve Aşağılama & 72 & 1.66 & 0.76 & 0.09 \\
\hline
\end{tabular}

Katılımcıların ölçek maddelerine verdikleri puanların alt boyutlar düzeyinde ortalamalarına bakıldığında en yüksek puanın ilgili tavır ve eylemler alt boyutunda, en düşük ortalamanın ise bir şey karşılığında bir şey isteme ve fiziksel saldırı alt boyutunda olduğu belirlenmiştir. Buradan hareketle katılımcıların misafirlerin cinsel taciz olgusunun tavır ve eylemler bağlamındaki rahatsızlıklarının daha fazla olduğu, misafirlerin sergilediği diğer uygunsuz davranışlardan ikinci en fazla görülen ise müstehcen tavırlar ve iletişim isteği olduğu, bunu sözlü taciz ve aşağılama içerikli davranışların izlediğini, fiziksel saldırı ve bir şey karşılığında bir şey isteme konularında ise daha az tacize uğradıkları ifade edilebilir.

\subsection{Güvenilirlik Analizi}

Tablo 3. Kullanılan ölçeğin ve ölçeğe ait faktörlerin Cronbach $\alpha$ Katsayıları

\begin{tabular}{clc}
\hline Ölçeğin Tamamı & \multicolumn{1}{c}{ Faktörler } & Katsayılar \\
\hline \multirow{4}{*}{$\boldsymbol{\alpha}=.954$} & İlgili Tavırlar ve Eylemler & $\alpha=.889$ \\
& Bir Şey Karşılığında Bir Şey İsteme ve Fiziksel Saldırı & $\alpha=.920$ \\
& Müstehcen Tavırlar ve İletişim İsteği & $\alpha=.840$ \\
& Sözlü Taciz ve Aşağıllama & $\alpha=.797$ \\
\hline
\end{tabular}

Araştırmada kullanılan ölçek ve alt boyutlarının güvenirlik katsayıları hesaplanmıştır. Ölçek geçerliklerine ait $\alpha$ katsayılarının .70 üzerinde olduğu dolayısıyla anketlerin güvenilir olduğu kanısına varılmıştır (Büyüköztürk, 2006).

\subsection{Normallik Testleri}

Tablo 4. Alt Boyut Puanlarına Ait Dağılımın Normalliğini Denetlemek Amacı ile Yapılan Bir Örneklem Kolmogorov-Smirnov Testi Sonuçları

\begin{tabular}{lccccc}
\hline Değerler & $\begin{array}{c}\text { İlgili Tavırlar } \\
\text { ve Eylemler }\end{array}$ & $\begin{array}{c}\text { Bir Şey Karşılı̆̆ında Bir } \\
\text { Şey İsteme ve Fiziksel } \\
\text { Saldırı }\end{array}$ & $\begin{array}{c}\text { Müstehcen Tavırlar } \\
\text { ve İletişim İsteği }\end{array}$ & $\begin{array}{c}\text { Sözlü Taciz ve } \\
\text { Aşağılama }\end{array}$ \\
\hline $\mathrm{N}$ & $\overline{\mathrm{X}}$ & 2.31 & 72 & 72 & 72 \\
Normal & $\mathbf{S S}$ & 0.85 & 1.16 & 1.97 & 1.66 \\
Parametreler & $\mathrm{SS}$ & 0.55 & 0.70 & 0.76 \\
Kolmogorov-Smirnov & .144 & .421 & .135 & .193 \\
$\mathrm{Z}$ & .001 & .000 & .003 & .000 \\
$\mathrm{p}$ & & & & \\
\hline
\end{tabular}

Verilerin normal dağılıma uygun olup olmadığını ortaya koymak amacıyla yapılan Kolmogorov-Smirnov testi sonucunda, ölçekten elde edilen puanların normal dağılım göstermediği $(\mathrm{p}<.05)$ tespit edilmiştir. 
Turist Rehberliği Dergisi (TURED) \& Yıl. 2019, Cilt. 2, Sayı. 2

Journal of Tour Guiding (JOTOG) \& Year. 2019, Volume. 2, Issue. 2

Tablo 5. Cinsel Taciz Ölçeği Puanlarının Cinsiyet Değişkenine Göre Farklılaşıp Farklılaşmadığını Belirlemek Üzere Yapılan Mann Whitney-U Testi Sonuçları

\begin{tabular}{|c|c|c|c|c|c|c|c|}
\hline Puan & Gruplar & $N$ & $\bar{x}_{\text {sira }}$ & $\sum_{\text {sira }}$ & $U$ & $z$ & $p$ \\
\hline İlgili Tavırlar ve Eylemler & $\begin{array}{l}\text { Kadin } \\
\text { Erkek } \\
\text { Toplam }\end{array}$ & $\begin{array}{l}37 \\
35 \\
72\end{array}$ & $\begin{array}{l}33.38 \\
39.80\end{array}$ & $\begin{array}{l}1235.00 \\
1393.00\end{array}$ & 532.000 & $\begin{array}{c}- \\
1.304\end{array}$ & .192 \\
\hline $\begin{array}{l}\text { Bir Şey Karşılığında Bir Şey İsteme ve } \\
\text { Fiziksel Saldırı }\end{array}$ & $\begin{array}{l}\text { Kadin } \\
\text { Erkek } \\
\text { Toplam }\end{array}$ & $\begin{array}{l}37 \\
35 \\
72 \\
\end{array}$ & $\begin{array}{l}32.47 \\
40.76\end{array}$ & $\begin{array}{l}1201.50 \\
1426.50\end{array}$ & 498.500 & 2.431 & .015 \\
\hline Müstehcen Tavırlar ve İletişim İsteği & $\begin{array}{l}\text { Kadın } \\
\text { Erkek } \\
\text { Toplam }\end{array}$ & $\begin{array}{l}37 \\
35 \\
72 \\
\end{array}$ & $\begin{array}{l}31.45 \\
41.84\end{array}$ & $\begin{array}{l}1163.50 \\
1464.50\end{array}$ & 460.500 & $\begin{array}{c}- \\
2.118\end{array}$ & .034 \\
\hline Sözlü Taciz ve Aşağılama & $\begin{array}{l}\text { Kadın } \\
\text { Erkek } \\
\text { Toplam }\end{array}$ & $\begin{array}{l}37 \\
35 \\
72\end{array}$ & $\begin{array}{l}38.07 \\
34.84\end{array}$ & $\begin{array}{l}1408.50 \\
1219.50\end{array}$ & 589.500 & -.668 & .504 \\
\hline
\end{tabular}

Ölçekten elde edilen puanların cinsiyet değişkenine göre farklılaşıp farklılaşmadığını belirlemek için yapılan Mann Whitney-U testi sonunda "Bir Şey Karşıllı̆ında Bir Şey İsteme ve Fiziksel Saldırı" ve "Müstehcen Tavırlar ve İletişim İsteği” alt boyutlarında gruplar arasında istatistiksel olarak anlamlı fark gözlemlenmiştir. Oluşan fark erkekler lehinedir. Başka bir değişle erkek katılımcıların sorular ile ifade edilen durumlara kadınlara oranla daha yüksek düzeyde muhatap oldukları sonucuna ulaşılabilir.

Tablo 6. Cinsel Taciz Ölçeği Puanlarının Medeni Durum Değişkenine Göre Farklılaşıp Farklılaşmadığını Belirlemek Üzere Yapılan Mann Whitney-U Testi Sonuçları

\begin{tabular}{llllllll}
\hline Puan & Gruplar & $N$ & $\bar{x}_{\text {sira }}$ & $\sum_{\text {sira }}$ & $U$ & $z$ & $p$ \\
\hline \multirow{2}{*}{ İlgili Tavırlar ve Eylemler } & Evli & 44 & 35.31 & 1553.5 & & & \\
& Bekâr & 28 & 38.38 & 1074.5 & 563.5 & -0.608 & 0.543 \\
& Toplam & 72 & & & & & \\
\hline \multirow{2}{*}{ Bir Şey Karş1lı̆̆ında Bir Şey } & Evli & 44 & 34.31 & 1509.5 & & & \\
İsteme ve Fiziksel Saldırı & Bekâr & 28 & 39.95 & 1118.5 & 519.5 & -1.614 & 0.106 \\
& Toplam & 72 & & & & & \\
\hline \multirow{2}{*}{ Müstehcen Tavırlar ve } & Evli & 44 & 33.86 & 1490 & & & \\
İletişim İsteği & Bekâr & 28 & 40.64 & 1138 & 500 & -1.347 & 0.178 \\
& Toplam & 72 & & & & & \\
\hline \multirow{2}{*}{ Sözlü Taciz ve Aşağılama } & Evli & 44 & 35.38 & 1556.5 & & & \\
& Bekâr & 28 & 38.27 & 1071.5 & 566.5 & -0.584 & 0.559 \\
& Toplam & 72 & & & & & \\
\hline
\end{tabular}

Ölçekten elde edilen puanların medeni durum değişkenine göre farklılaşıp farklılaşmadığını belirlemek için yapılan Mann Whitney-U testi sonunda gruplar arasında istatistiksel olarak anlamlı fark gözlemlenmemiştir. 
Turist Rehberliği Dergisi (TURED) \& Yıl. 2019, Cilt. 2, Sayı. 2

Journal of Tour Guiding (JOTOG) \& Year. 2019, Volume. 2, Issue. 2

Tablo 7. Cinsel Taciz Ölçeği Puanlarının Yaş Değişkenine Göre Farklılaşıp Farklılaşmadığını Belirlemek Üzere Yapılan Kruskal Wallis-H Testi Sonuçları

\begin{tabular}{|c|c|c|c|c|c|c|}
\hline Alt Boyut & Gruplar & $N$ & $\bar{x}_{\text {sira }}$ & $x^{2}$ & $s d$ & $p$ \\
\hline \multirow{4}{*}{$\begin{array}{l}\text { İlgili Tavırlar } \\
\text { ve Eylemler }\end{array}$} & $<30$ & 11 & 37.36 & \multirow{4}{*}{1.04} & \multirow{4}{*}{3} & \multirow{4}{*}{.791} \\
\hline & $31-35$ & 12 & 39.46 & & & \\
\hline & $36-40$ & 10 & 30.7 & & & \\
\hline & $40<$ & 39 & 36.83 & & & \\
\hline \multirow{4}{*}{$\begin{array}{l}\text { Bir Şey Karşılı̆̆ında } \\
\text { Bir Şey İsteme ve } \\
\text { Fiziksel Saldırı }\end{array}$} & $<30$ & 11 & 36.23 & \multirow{4}{*}{.606} & \multirow{4}{*}{3} & \multirow{4}{*}{.895} \\
\hline & $31-35$ & 12 & 36.33 & & & \\
\hline & $36-40$ & 10 & 33.45 & & & \\
\hline & $40<$ & 39 & 37.41 & & & \\
\hline \multirow{4}{*}{$\begin{array}{l}\text { Müstehcen Tavırlar } \\
\text { ve İletişim İsteği }\end{array}$} & $<30$ & 11 & 41 & \multirow{4}{*}{2.303} & \multirow{4}{*}{3} & \multirow{4}{*}{.512} \\
\hline & $31-35$ & 12 & 38.54 & & & \\
\hline & $36-40$ & 10 & 28 & & & \\
\hline & $40<$ & 39 & 36.78 & & & \\
\hline \multirow{4}{*}{$\begin{array}{l}\text { Sözlü Taciz ve } \\
\text { Aşağılama }\end{array}$} & $<30$ & 11 & 35.18 & \multirow{4}{*}{.404} & \multirow{4}{*}{3} & \multirow{4}{*}{.932} \\
\hline & $31-35$ & 12 & 36.25 & & & \\
\hline & $36-40$ & 10 & 33.3 & & & \\
\hline & $40<$ & 39 & 37.77 & & & \\
\hline
\end{tabular}

Ölçekten elde edilen puanların katılımcıların yaşına bağlı olarak farklılaşıp farklılaşmadığını belirlemek için yapılan Kruskal Wallis-H testi sonunda gruplar arasında istatistiksel olarak anlamlı fark gözlemlenmemiştir.

Tablo 8. Cinsel Taciz Ölçeği Puanlarının Çalışma Süresi Değişkenine Göre Farklılaşıp Farklılaşmadığını Belirlemek Üzere Yapılan Kruskal Wallis-H Testi Sonuçları

\begin{tabular}{|c|c|c|c|c|c|c|}
\hline Alt Boyut & Gruplar & $N$ & $\bar{x}_{\text {sira }}$ & $x^{2}$ & $s d$ & $p$ \\
\hline \multirow{4}{*}{$\begin{array}{l}\text { İlgili Tavırlar } \\
\text { ve Eylemler }\end{array}$} & $1-5$ y1l & 12 & 30.58 & \multirow{4}{*}{1.305} & \multirow{4}{*}{3} & \multirow{4}{*}{.728} \\
\hline & $6-10$ y1l & 12 & 36.21 & & & \\
\hline & $11-20 \mathrm{y} 11$ & 21 & 37.12 & & & \\
\hline & $20+y 11$ & 27 & 38.78 & & & \\
\hline \multirow{4}{*}{$\begin{array}{l}\text { Bir Şey Karşılığında } \\
\text { Bir Şey İsteme ve } \\
\text { Fiziksel Saldırı }\end{array}$} & $1-5$ y1l & 12 & 32.13 & \multirow{4}{*}{3.161} & \multirow{4}{*}{3} & \multirow{4}{*}{.367} \\
\hline & $6-10$ y1l & 12 & 33.04 & & & \\
\hline & $11-20 \mathrm{y} 1 \mathrm{l}$ & 21 & 40.12 & & & \\
\hline & $20+y 11$ & 27 & 37.17 & & & \\
\hline \multirow{4}{*}{$\begin{array}{l}\text { Müstehcen Tavırlar } \\
\text { ve İletişim İsteği }\end{array}$} & $1-5 \mathrm{y} 1 \mathrm{l}$ & 12 & 34.33 & \multirow{4}{*}{.858} & \multirow{4}{*}{3} & \multirow{4}{*}{.836} \\
\hline & $6-10$ y1l & 12 & 32.54 & & & \\
\hline & $11-20 \mathrm{y} 11$ & 21 & 38.67 & & & \\
\hline & $20+y 11$ & 27 & 37.54 & & & \\
\hline \multirow{4}{*}{$\begin{array}{l}\text { Sözlü Taciz ve } \\
\text { Aşağılama }\end{array}$} & $1-5$ y1l & 12 & 31.04 & \multirow{4}{*}{1.815} & \multirow{4}{*}{3} & \multirow{4}{*}{.612} \\
\hline & $6-10$ y1l & 12 & 33.25 & & & \\
\hline & $11-20 \mathrm{y} 1 \mathrm{l}$ & 21 & 37.52 & & & \\
\hline & $20+y 11$ & 27 & 39.57 & & & \\
\hline
\end{tabular}

Ölçekten elde edilen puanların katılımcıların çalışma süresine bağlı olarak farklılaşıp farklılaşmadığını belirlemek için yapılan Kruskal Wallis-H testi sonunda gruplar arasında istatistiksel olarak anlamlı fark gözlemlenmemiştir. 
Turist Rehberliği Dergisi (TURED) \& Yıl. 2019, Cilt. 2, Sayı. 2

Journal of Tour Guiding (JOTOG) \& Year. 2019, Volume. 2, Issue. 2

Tablo 9. Cinsel Taciz Ölçeği Puanlarının Eğitim Düzeyi Değişkenine Göre Farklılaşıp Farklılaşmadığını Belirlemek Üzere Yapılan Kruskal Wallis-H Testi Sonuçları

\begin{tabular}{|c|c|c|c|c|c|c|}
\hline Alt Boyut & Gruplar & $N$ & $\bar{x}_{\text {sira }}$ & $x^{2}$ & $s d$ & $p$ \\
\hline \multirow{4}{*}{$\begin{array}{l}\text { İlgili Tavırlar } \\
\text { ve Eylemler }\end{array}$} & Lise & 3 & 32.5 & \multirow{4}{*}{1.189} & \multirow{4}{*}{3} & \multirow{4}{*}{0.756} \\
\hline & Ön Lisans & 2 & 44.5 & & & \\
\hline & Lisans & 40 & 38.35 & & & \\
\hline & Lisansüstü & 27 & 33.88 & & & \\
\hline \multirow{4}{*}{$\begin{array}{l}\text { Bir Şey Karşılığında } \\
\text { Bir Şey İsteme ve } \\
\text { Fiziksel Saldırı }\end{array}$} & Lise & 3 & 35.8 & \multirow{4}{*}{0.744} & \multirow{4}{*}{3} & \multirow{4}{*}{0.863} \\
\hline & Ön Lisans & 2 & 29.5 & & & \\
\hline & Lisans & 40 & 36.05 & & & \\
\hline & Lisansüstü & 27 & 37.85 & & & \\
\hline \multirow{4}{*}{$\begin{array}{l}\text { Müstehcen Tavırlar } \\
\text { ve İletişim İsteği }\end{array}$} & Lise & 3 & 41.4 & \multirow{4}{*}{2.378} & \multirow{4}{*}{3} & \multirow{4}{*}{0.498} \\
\hline & Ön Lisans & 2 & 26.75 & & & \\
\hline & Lisans & 40 & 39.14 & & & \\
\hline & Lisansüstü & 27 & 32.35 & & & \\
\hline \multirow{4}{*}{$\begin{array}{l}\text { Sözlü Taciz ve } \\
\text { Aşağılama }\end{array}$} & Lise & 3 & 32.1 & \multirow{4}{*}{0.72} & \multirow{4}{*}{3} & \multirow{4}{*}{0.868} \\
\hline & Ön Lisans & 2 & 28.75 & & & \\
\hline & Lisans & 40 & 36.27 & & & \\
\hline & Lisansüstü & 27 & 38.29 & & & \\
\hline
\end{tabular}

Ölçekten elde edilen puanların katılımcıların eğitim düzeyine bağlı olarak farklılaşıp farklılaşmadığını belirlemek için yapılan Kruskal Wallis-H testi sonunda gruplar arasında istatistiksel olarak anlamlı fark gözlemlenmemiştir.

Araştırma anketinin sonuna cinsel taciz konusu ile ilgili açık uçlu bir soru eklenmiştir. "Cinsiyet temelli karşılaşılabilen sorunlar ve mesleğinize etkileri ile ilgili görüşleriniz nelerdir? (Tur yönetimi sürecinde tecrübeleriniz, önlem - çözüm önerileriniz ve yasal mevzuat ile ilgili bilgileriniz)' şeklinde katılımcılara yöneltilen açık uçlu soruya 21 katılımcı cevap vermiştir.

Nitel verilerin analizi kısmında öncelikle katılımcıların cinsel taciz ile ilgili belirttikleri görüşler bir Word belgesinde toplanmıştır. Sonrasında elde edilen verilerin tamamı okunmuş ve veriler benzer gruplar altında düzenlenmiştir. Bu düzenlemeler bağlamında temalar oluşturulmuştur. Temaların oluşturulmasında betimsel kodlamadan faydalanılmıştır. gibidir:

Açık uçlu sorunun betimsel analizi sonucunda 5 temada toplanan bulgular aşağıdaki

\section{Turistlerden Görülen Uygunsuz Davranışlar:}

E-5 "31 yıllık meslek hayatımda zaman zaman tacizle karşılaşsam da müsteri-rehber dialoğu dişında asla profesyonellikten taviz vermedim, kibar bir dil ile bu durumlar görmezden geldim."

K-1 "Meslek odamızın konuyla ilgili bir bilgilendirmesi olmamıştır. Tur yönetimi çerçevesinde grupla iletişim bu konuda çok önemli diye düşünüyorum. Ölçülü bir dialog, tabi ki grup dinamiğini bozmamak kaydıyla, bu tarz problemlerin yaşanmaması adına bir önlem olabilir."

K-13, E-2, K18, K,12, E-6 “Mesafe iyidir, bazen de saf, anlamamıs gibi davranmak." 
Turist Rehberliği Dergisi (TURED) \& Yıl. 2019, Cilt. 2, Sayı. 2

Journal of Tour Guiding (JOTOG) \& Year. 2019, Volume. 2, Issue. 2

\section{İş arkadaşlarından görülen uygunsuz davranışlar:}

K-2 "Tur müşterileri haricinde acenta çalışanları ve tur programında uğranılan mağaza sahipleri ve oradaki çalışanlar tarafindan da cinsel yakınlaşma çabası gördüm."

K-6 "Kadın rehberlerin kendi meslektaşlarını ve kaptan söför vb. camiadan gördükleri mobbingi araştırmanız daha doğru olurdu."

E-11 "Bu konu tamamen kişinin kendisiyle alakalıdır. Bu tip eğilimlerde olan meslektaşlarım oldukça fazla. Bizim işimizin ne çok samimi ne çok resmî olmasından kaynaklanan ve kişinin sadece duruşuyla / bakış açısıyla çözülebilir. Bunun mesleki eğitimle bir alakası olduğunu düşünmüyorum."

K-7 "Yaşadiğım iş birakmamı düşündürecek cinsel temelli sorun tur esnasında misafirle değil şirkette operasyon müdürüyle olmuştur. Tur yönetimi sürecinde misafirden gelen basit beğeni hoşnutluk üzerine gelişebilecek sorunlar, sizin göstereceğiniz profesyonellik ve kibar uyarılarla büyümeyecektir. En azından ben şahsımda bu şansı yakalamıştım."

K-8 "Misafirlerden çok içinde çalıştı̆̆ımız ortamda çalışan kadına kötü gözle bakan sosyal çevrenin, şöforle iktidar mücadelesinin, diğer meslektaş tacizlerinin ki ille de cinsel olarak araștırılması eksik kalmaktadır, kadın olma baskısı her an hissedilir."

$\mathrm{K}-10, \mathrm{~K}-16, \mathrm{~K}-9, \mathrm{~K}-17$ "Bu sorulart misafirlerle ilgili değil de meslektaş ve acentacıları kapsar şekilde yapmanız daha faydalı olur."

K-19 "Misafirler tarafindan değil genellikle turizm çevresi tarafindan zor durumlarda bırakıllyoruz. Bir kadın veya bir erkek her ne olursa olsun işini yapmak için ordaysa böyle şeyler ile karşılaşmamaktadır."

K-14 "Bir kadin rehber olarak misafirle de turizmde çalışan personelle de mesafeyi baştan korumak gerektiği inancındayım. Kadın rehberlerin cinsiyetleri nedeniyle sorun yaşadiğı taraflar arasında misafirlerden çok acenteci, şoför, mă̆aza elemanı vs gibi meslek sahipleri yer allyor."

E-4 "Bence ne olur ne olmaz gibisinden rehber arkadaşlar anlatımları esnasında her kişiye eşit oranda göz teması sağlamalı ki karşı taraf bir beklentiye girmesin. Ayrıca bu konuda şoförler, turistleri bir cinsel obje ve kendileriyle kolayca uygunsuz iletissim kurabilecekleri hafif meşrep bayanlar olarak görmemeleri hususunda uyarılmalıdır. Şoförlerimiz dedim özellikle ama turizmde çalışan tüm erkekler için bu yaklaşım söz konusu."

\section{Cinsel taciz ile ilgili caydırıcı cezalandırmaların gerekliliği:}

K-20 "Cinsiyet temelli sorunlar her meslek grubunu etkilediği gibi turist rehberliğini de oldukça etkilemektedir. Özellikle uzun saatler bir arada bulunma ve mesleğimiz gereği her konuda yardımcı olduklarından bu durum turistler tarafindan kişisel algılanmakta ve zaman zaman sözlü tacize maruz kalmama sebep olmaktadır. Bu durumlar ülkenin kanayan yarası maalesef. Dolayısıyla caydırıcı cezalar olmadıkça bu durum devam etmeye mahkûm. Özellikle kadın olarak bakmıyorum olaya... Bugün erkek meslektaşlarımız da aynı durumlarla karşı karşıya kalabiliyor."

K-5 "Ĕ̆er cinsel taciz veya rahatsı edici bir durum varsa erkek veya bayan rehber acenta, rehberler odası, TÜRSAB turizm müdürlüklerine durumu iletmeli ve gerekli cezalar müşteriye verilmeli. Basında da teşhiri yapılmalı ki caydırıcı bir yanı olsun." 
K-13 "Mesafeyi korumakta her zaman fayda var diye düşünüyorum. Fakat sapkın insanlar için yapılacak en iyi şey uyarı sonrası, gerekli mercilere şikâyet olmalı. Ben şu ana kadar böyle ciddi bir problemle karşılaşmadım. Sadece karşıdaki kişinin beğenisini gösteren bazı hareketler ve iltifatlar oldu ama zaten bu normal bir durum ve karşı taraftan bir karşıllk gelmeyince sonlaniyor. Sonrasında bir rahatsız edilme yaşamadım."

\section{Cinsiyet ayrumcilı̆̆ı:}

K-6 "Yurtdışı turlarda kadın kıskançlı̆̆ sebebiyle erkek rehberler tercih ediliyor."

K-11 "Mesleğimizde cinsel ayrımcılık yapılması en büyük sorunumuzdur. Özellikle yurtdlşı turlarında birçok şirket erkek rehberle çalışmayı tercih etmektedir. Yurtdışı turları yapan şirketler bayileri için seks turizmi düzenlemekte ve rehber meslektaşlarımızı da buna alet etmektedirler. Onlar da para kazanmak için herşeyi yapmaktadır. Erkek rehberlerin bayan yolculardan tacize uğradĭ̆ ve ilişki kurduğu vakalar daha çoktur."

K-15 "Genel anlamda erkek rehberlerin kadın rehberlerden daha iyi olduğu düşünülüyor. Ne yazık ki özellikle hemcinslerimiz kadın misafirler bu önyarglya sahipler.”

\section{Diğer katılımcılar tur esnasında cinsiyet temelli bir sorun yaşamadı̆̆ yönünde görüşlerini bildirmiştir:}

K-3 "Karşılaşmadım. İhtimal dâhilinde olmadiğını düşünmek istiyorum."

K-4 "Cinsiyetle ilgili bir sorunla hiç karşılaşmadım."

E-1 "Büyük önemi olmadı̆̆ıı düşünüyorum."

E-3 "Cinsiyet temelli sorunların rehberlik mesleğine çok önemli etkileri olduğunu düşünmüyorum. Bu görüşüm tabii ki erkek rehberler için geçerli. Bayan rehberler için bazı sorunların olabileceğini düşünüyorum."

Beş temada gruplandırılarak incelenen nitel bulguların araştırmanın nicel bulgularıyla örtüştüğü görülmektedir. Genel olarak turist rehberleri cinsel taciz kapsamlı yaklaşımlar fark ettiğinde bunu turist psikolojisini göz önünde bulundurarak, grup dinamiğini ve tur yönetimini bozmadan tatlı dille espriyle yaklaşarak veya görmezden gelmek suretiyle idare ettiğini ifade etmişlerdir. Fakat nicel sorularda olmayan ve açık uçlu soruda rehberlerin özellikle dile getirmek istediği cinsiyet temelli sorunlar kapsamında cinsel taciz yaklaşımlarını ne yazık ki çoğunlukla tur personelinden görmekte olduklarını ve bu durumdan çok rahatsız olduklarını belirtmişlerdir. Profesyonel turist rehberlerinin tur süresince birlikte çalıştığı acenta personeli ve ziyaret noktalarındaki işletme çalışanlarından cinsel taciz içerikli yaklaşımlar görmesi mesleğini olumsuz etkileyen problemlerden biri olarak tespit edilmiştir ve rehberler bu konuyla ilgili araştırma yapılmasını talep etmektedir. İletişim kabiliyetiyle, yanlış tavırlar sergilemeye meyilli misafirlerin ya da çalışma arkadaşlarının cinsel taciz içerikli davranışlarının engellenmesinin mümkün olduğunu ifade eden turist rehberleri çoğunlukla bu şekilde böyle bir sorun yaşamadıklarını ifade etmiştir. Bu araştırmanın nitel bulgularında öne çıkan ve önceki araştırmalardan farklı olan bulgu ise, erkek rehberlerin kadın rehberlerden daha kaliteli hizmet ettiği yönünde bir turist algıSı olmasıdır. Nicel bulgularda ise, çoğunlukla erkek katılımcıların "Bir Şey Karşılığında Bir Şey İsteme ve Fiziksel Saldırı" ve "Müstehcen Tavırlar ve İletişim İsteği" içerikli cinsel taciz tutumlarına, kadın rehberlere göre daha fazla maruz kaldıkları sonucu ortaya çıkmıştır. 17 kadın ve 6 erkek rehberden alınan nitel verilere göre, erkek rehberler cinsel taciz konulu bir problem fark ettiğinde görmezden gelmeyi tercih etmekte ve bunu meslekleri için çok büyük bir engel olarak değerlendirmemektedir. Kadın rehberler ise çoğunlukla iş arkadaşlarından cinsel taciz yaklaşımı gördüğü belirtmiştir. Kadın rehberler, meslekte bir cinsiyet ayrımcılığı yapıldığını ve daha çok erkek rehberlerin turlarda daha iyi anlatım yaptıkları 


\section{IIIII)}

Turist Rehberliği Dergisi (TURED) \& Y11. 2019, Cilt. 2, Sayı. 2

Journal of Tour Guiding (JOTOG) \& Year. 2019, Volume. 2, Issue. 2

düşünüldüğü için tercih edildiklerini belirtmiştir. Kadın rehberler turist rehberlerine yönelik cinsel taciz konusu ile ilgili yaptırımlar, cezalandırmalar olması gerektiği yönünde görüş bildirmiştir.

Hangi bölgelerde cinsel taciz sorunun var olduğunu tespit etmek amaciyla rehberlere anket soruları dâhilinde çalışma bölgeleri sorulmuştur. Cevapların betimsel analizi sonucunda, araştırmaya katılan katılımcılardan 56 turist rehberi Marmara bölgesinde çalışmakta olduğu görülmüştür. 41 rehber Ege bölgesi turlarına da katılmaktadır. 37'si İç Anadolu bölgesi turlarına da çıktığını belirtmiştir. 33 rehber Akdeniz turlarında çalıştığını belirtmiştir. Güneydoğu Anadolu Bölgesi'nde çalışan rehberler 18 ve Doğu Anadolu Bölgesi'nde çalışan rehberler 12 kişiyle sınırlı kalmıştır. Dolayısıyla doğu turlarına çıkan rehberlerden araştırmaya katılmayı kabul eden turist rehberi sayısı daha az olmuştur. 21 rehber Karadeniz turlarında çalışmaktadır. 20 rehber yurtdışı turlarına da katılmaktadır.

Turist rehberleri, misafirlerle tatil başlangıcından sonuna kadar sürekli iletişim halinde olan turizm profesyonelleridir. Turist psikolojisi ile seyahat halinde olan bireyler, lider vasıflı turist rehberleri ile bu iletişimlerinde etik dışı tutumlar sergileyebilmektedir. Bazen psikolojik bazen de güç dengesi sebepli oluşabilen bu tutumlar, profesyonel turist rehberlerinin iletişim kabiliyetleriyle yönetmesi gereken bir mesleki problemdir.

\section{Sonuç ve Öneriler}

Literatürde genel olarak kadın rehberlerin meslekte yaşadığı cinsiyet temelli sorunlar irdelenmiştir ve örneğin Zengin vd., tarafından 2014 yılında yapılan bir araştırmaya göre, kadın rehberlerin taciz ve yıldırma gibi sorunlarla daha çok karşı karşıya kaldıkları tespit edilmiştir. Buna karşın, Erkol Bayram vd. tarafından 2018 yılında yapılan diğer bir araştırmaya göre kadın turist rehberlerinin cinsiyet ayrımı gibi bir sorun yaşamadığı, erkek rehberlerle aynı mesleki sorunlarla karşılaştığı ve genel olarak mesleklerinden memnun oldukları tespiti söz konusudur. $\mathrm{Bu}$ araștırmaların devamı niteliğinde, turist rehberlerinden hem anket soruları hem de açık uçlu bir soruyla cinsel taciz sorununun var olup olmadığı ve eğer varsa bu konudaki görüşlerini kendi ifadeleri ile dile getirmeleri istenmiştir. Bu amaçla Türkiye'deki tüm rehberlere ulaşma teşebbüsleri gerçekleşse de, bu konuda 72 turist rehberi cevap vermeyi kabul etmiştir. Konunun hassasiyeti sebebiyle az katılımcının görüş vermeyi kabul ettiği düşünülebilir.

Türkiye'nin tüm bölgelerinde çalışan rehberlere ulaşılması araştırma örnekleminin evreni temsil etme gücü açısından memnuniyet vericidir. Bulgular incelendiğinde, daha çok Marmara, Ege ve İç Anadolu bölgesinde çalışmakta olan rehberlerin tecrübelerini aktardığı görülmektedir. Önceki araştırmaların (Eller, 1990; Hoel ve Einarsen, 2003) aksine, araştırma ölçeğindeki "Bir Şey Karşıllı̆ında Bir Şey İsteme ve Fiziksel Saldırı" ile "Müstehcen Tavırlar ve İletişim İsteği”" alt boyutlarındaki sonuca göre erkek rehberlerin cinsel taciz sorunuyla, kadın rehberlere kıyasla daha çok karşılaştıkları bulgusu ortaya çıkmıştır. Araştırma ölçeğine eklenen açık uçlu soruda, cinsel taciz eğilimi olan turistlerle karşılaşıldığ 1 fakat bu tutumu görmezden gelme ya da iletişim kabiliyeti ile çatışma haline getirmeden yok etme gibi yöntemlerle idare edildiği yönünde bulgular mevcuttur. Katılımcılar, grupta her turistle eşit göz teması kurmanın dahi bu gibi sorunların önüne geçebildiğini ifade etmiş̧lerdir. Araştırmanın nitel bulguları incelendiğinde, profesyonel turist rehberliği mesleğinde, turist rehberlerinin turistlerden ve çalışma arkadaşlarından cinsel taciz içerikli uygunsuz davranışlar gördüğü, bu meslekte cinsiyet ayrımcılığının söz konusu olduğu ve turistler nezdinde, erkek rehberlerin daha kaliteli hizmet verdiği algısı olduğu, cinsel taciz konulu caydırıcı cezalandırmaların olması gerekliliği tespit edilmiştir. 
Araştırmada ulaşılabilir evrenin sadece 3 rehber odası olması ve bu odalarda kayıtlı 72 turist rehberinin geri dönüş vermesinin yanı sıra, yalnızca turist rehberleri ve turistlerin iletişiminden ortaya çıkabilecek bir sorunu irdelemesi de bir sınırlılık olarak kabul edilebilir. Turist rehberlerinin tüm çalışma arkadaşları ve paydaşları ile ilgili bir araştırma yapılması gerekliliği, katılımcıların özellikle turda görevli personel ve acenta yetkililerinden cinsel taciz yaklaşımları gördüklerini ifade etmelerinden anlaşılmaktadır. Konuyla ilgili sonraki araştırmaların bu yönde daha geniş kapsamlı olması önerilmektedir.

\section{Kaynakça}

Alrawadieh, Z., Alrawadieh, Z., ve Kozak, M. (2019). Exploring the Impact of Tourist Harassment on Destination Image, Tourist Expenditure, and Destination Loyalty. Tourism Management, 73, 13-20.

Antecol, H., Barcus, V.E., ve Cobb-Clark, D. (2009). Gender-Biased Behavior at Work: Exploring the Relationship between Sexual Harassment and Sex Discrimination. Journal of Economic Psychology, 30(5), 782-792.

Arslan, M. ve Vasılyeva, M. (2003). İşyerinde Algılanan Cinsel Tacizin Kültürler Arası Farkı; Türkiye ve Rusya-Saha Cumhuriyetinde Bir Uygulama, 11. Ulusal Yönetim ve Organizasyon Kongresi, Mayıs, Afyon, 461-462.

Becton, J.B., Gilstrap, J.B., ve Forsyth, M. (2017). Preventing and Correcting Workplace Harassment: Guidelines for Employers. Business Horizons, 60(1), 101-111.

Büyüköztürk. Ş. (2006). Soysal Bilimler İçin Veri Analizi El Kitabı. Ankara: Pegem Yayınları

Creswell, J.W., \& Clark, V.L.P. (2017). Designing and Conducting Mixed Methods Research. Sage publications.

Eller, M. E. (1990). Sexual Harassment in the Hotel Industry: The Need to Focus on Prevention. Hospitality Research Journal, 14(2), 431-440.

Erkol Bayram, G., Keskin, M., İpar, M.S. ve Ak, S. (2018). Kadın Rehberlerin Toplumsal Rolleri ve Çalışma Yaşamında Karşılaştıkları Cinsiyet Temelli Sorunlar, İçinde: N. Hacıoğlu, C. Avcıkurt, A. Kılıç, H. Ulusoy Yıldırım (Ed.). Turist Rehberliği Üzerine Güncel Araştırmalar, 456-467, Ankara: Detay Yayıncılık.

European Commission (1998). Sexual Harassment in the Workplace in the European Union. European Commission, Brussells.

Faley, R. H., Knapp, D. E., Kustis, G. A., Dubois, C. L., Young, J. ve Polin, B. (2006). Estimating the Organizational Costs of Same-Sex Sexual Harassment: The Case of the US Army. International Journal of Intercultural Relations, 30(5), 557-577.

Gilbert, D., Guerrier, Y., Guy, J., (1998). Sexual Harassment Issues in the Hospitality Industry. International Journal of Contemporary Hospitality Management, 10 (2), 48-53.

Hoel, H. ve Einarsen, S. (2003). Violence at work in hotels, catering and tourism. International Labous Office.

Huang, F. Y. (1995). A Study of Sexual Harassment at Workplace and Its Prevention. Shih Shuo, $82,28-36$.

Koparan, E. ve Yücel, B. E. (2010). Güç Mesafesi ve Cinsel Taciz Davranışları Arasındaki İlişkinin Yönünü Belirlemeye Yönelik Görgül Bir Çalışma. Organizasyon ve Yönetim Bilimleri Dergisi, 2(1), 11-18.

Leavy, Patricia (2014). The Oxford Handbook of Qualitative Research. Oxford Library of Psychology, 198 Madison Avenue, New York, 1-773.

Lin, Y. H. (2006). The Incidence of Sexual Harassment of Students While Undergoing Practicum Training Experience in the Taiwanese Hospitality Industry-Individuals Reactions and Relationships to Perpetrators, Tourism Management, 27(1), 51-68.

Lincoln, Yvonna S., Guba, Egon, G. (1985). Naturalistic Inquiry. Beverly Hills, CA:Sage. 
Luthar H. K. ve Luthar, V. K. (2007). A Theoretical Framework Explaining Cross-Cultural Sexual Harassment: Integrating Hofstede and Schwartz, Journal of Labor Research, XXVIII, (1), 169-188.

Luthar, H. K. ve Pastille, C. (2000). Modeling Subordinate Perceptions of Sexual Harassment: The Role of Superior-Subordinate Social-Sexual Interaction, Human Resource Management Review, 10(2), 211-244.

Merkin, R. (2009). South American Perspectives on Sexual Harassment: The Standpoint in Argentina, Brazil, and Chile, Journal of Behavioral and Applied Management, 10, 357-376.

Mimaroğlu, A. G. H. ve Özgen, H. (2008). Örgütlerde Güç Eşitsizlikleri ve Cinsel Taciz. Çukurova Üniversitesi Sosyal Bilimler Enstitüsü Dergisi, 17(1), 321-334.

Mkono, M. (2010). Zimbabwean Hospitality Students' Experiences of Sexual Harassment in the Hotel Industry. International Journal of Hospitality Management, 29(4), 729-735.

O'Donohue, W., Downs, K. ve Yeater, E. A. (1998). Sexual Harassment: A Review of the Literature. Aggression and Violent Behavior, 3(2), 111-128.

Oktay, A. (2001). İşyerinde Cinsel Taciz ve İstismar. Kadın Araştırmaları Dergisi, (7).

Posner, R. A. (1999). Employment Discrimination: Age Discrimination and Sexual Harassment. International Review of Law and Economics, 19(4), 421-446.

Poulston, J. (2008). Hospitality Workplace Problems and Poor Training: A Close Relationship. International Journal of Contemporary Hospitality Management, 20(4), 412-427.

Publication Ltd., London, 1-240.

Reilly, M. E., Lott, B. ve Gallogly, S. M. (1986). Sexual Harassment of University Students. Sex Roles, 15(7-8), 333-358.

Saldana, Johnny (2009). The Coding Manual for Qualitative Researchers. Sage

Saunders, S. ve AM, P. E. (2013). The Nature, Pervasiveness and Manifestations of Sexual Harassment in Rural Australia: Does "Masculinity" of Workplace Make A Difference? In Women's Studies International Forum, 40, 121-131, Pergamon.

Schneider, M. ve Phillips, S. P. (1997). A Qualitative Study of Sexual Harassment of Female Doctors by Patients. Social Science \& Medicine, 45(5), 669-676.

Solmuş, T. (2005). İş Yaşamında Travmalar: Cinsel Taciz Ve Duygusal Zorbalık/Taciz (Mobbing). ISGUC The Journal of Industrial Relations and Human Resources, 7(2), 1-14.

Sözer, M.A. ve Clevenger, S. (2010). Üniversite Kampüslerinde Uygulanan Tecavüz ve Cinsel Tacizi Önleme Eğitim Programlarının Etkililiği. Eskişehir Osmangazi Üniversitesi Sosyal Bilimler Dergisi, 11(1), 89-121.

Spector, P. E., Zhou, Z. E. ve Che, X. X. (2014). Nurse Exposure to Physical and Nonphysical Violence, Bullying, and Sexual Harassment: A Quantitative Review. International Journal of Nursing Studies, 51(1), 72-84.

Timmerman, G. ve Bajema, C. (1999). Sexual Harassment in Northwest Europe. European Journal of Women's Studies, 6(4), 419-439.

Ullman, S. E. (2007). A 10-year update of "Review and Critique of Empirical Studies of Rape Avoidance". Criminal Justice and Behavior, 34 (3), 411-429.

Unur, K. ve Şanlı, S. C. (2018). Staj Yapan Öğrencilere Yönelik Cinsel Taciz: Otel İşletmeleri Örneği. Journal of Travel and Hospitality Management, 15(1), 149-161.

Wasti, S.A., Bergman, M.E., Glomb, T.M. ve Drasgow. F. (2000). Test of the Cross Cultural Generalizability of a Model of Sexual Harassment, Journal of Applied Psychology, 85(5), 766-778.

West, C. ve Fenstermaker, S. (1995). Doing difference. Gender \& Society, 9(1), 8-37.

Woods, R. H. ve Kavanaugh, R. R. (1994). Gender Discrimination and Sexual Harassment as Experienced by Hospitality-Industry Managers: More Than 80 Percent of The Men and Women Surveyed Perceive Gender Discrimination and Sexual Harassment in the Workplace 


\section{IIIII)}

Turist Rehberliği Dergisi (TURED) \& Y11. 2019, Cilt. 2, Sayı. 2

Journal of Tour Guiding (JOTOG) \& Year. 2019, Volume. 2, Issue. 2

as an Ongoing Problem. Cornell Hotel and Restaurant Administration Quarterly, 35(1), 1621.

Worsfold, P. ve McCann, C. (2000). Supervised Work Experience and Sexual Harassment. International Journal of Contemporary Hospitality Management, 12(4), 249-255.

Zengin, B., Eker, N. ve Erkol Bayram, G. (2017). Turist Rehberliği Meslek Kanununun Profesyonel Turist Rehberlerince Değerlendirilmesi. Seyahat ve Otel İsletmeciliği Dergisi, 14(2), 142-156. 